\title{
Stakeholder Influence on Corporate Strategies Over Time
}

\section{Waymond Rodgers Susana Gago}

ABSTRACT. Modern management reporting on its company's performance is influenced by individuals' ethical considerations. Stakeholders' philosophies have continued to change over the last 75 years affecting reporting systems for companies reporting information internally and externally. These fundamental changes in philosophy have affected how information is conveyed. We are not claiming that only one philosophical view point dominates companies reporting practices, but there does appear to be a changing trend of philosophies building on one another. We use resource dependence theory in relationship to a decision making model to explain changing stakeholders positions over time. This paper argues that six dominant philosophical theories have influenced the way individuals and organizations report financial and other information. Further, these philoso phies then are depicted in a model that helps us to understand what influences companies to present them selves to the outside world. A vignette is used to depict changing philosophical views for several companies' management report over 75 years.

Waymond Rodgers is Professor and Chairperson of the Accounting Department in Gary A. Anderson Graduate School of Man agement, University of California Riverside. Postdoctorate, Emphasis: Cognitive Psychology, University of Michigan Ph.D., Accounting, University of Southern California MBA, Finance, University of Detroit B.A., Accounting, Michigan State University. Waymond Rodgers' research and teaching interest is in decision processes of users of information. The Throughput Model developed by Professor Rodgers for organi zational decision making is a conceptualization of individuals' perception (problem framing and biases), information (available to the individual), judgment (analysis), and decision choice. This model is also important in highlighting the influence of ethical behavior in the model dominant pathways to a decision. Professor Rodgers has published in Accounting Business Re search, Journal of Accounting Literature, Journal of Accounting and Public Policy, Journal of Applied Social Psychology, Journal of Business Ethics, Management Science, among others.
KEY WORDS: Throughput model, cognitive processes, ethical behavior, decision making.

\section{Introduction}

Companies' management publishes annual account ing reports. One purpose of these reports is to com municate with stakeholders. The emphasis placed on certain stakeholders' in a company's annual report is indicating the stakeholders' leverage over the com pany (Frooman, 1999). Mitchell et al. (1997) argue that possessing any of the following three dimensions makes a group a latent stakeholder, whereas a defin itive stakeholder possess all three:

Susana Gago is Associate Professor of Accounting in Carlos III University of Madrid. She is on leave from Universidad de Santiago de Compostela, She also collaborates with instituto de Empresa and ISCAC of Coimbra. Ph.D.: Economics and Business, Universidad de Santiago de Compostela. Master in Auditing: Spanish institute of Certified Public Accountants (ICAC) and University of Santiago de Compostela. MBA: University of Santiago de Compostela. B.A.: Economics and Business, Universidad de Santiago de Compostela. Susana Gago's research and teaching interest is in management, $f i$ nancial and public accounting. Her concerns regarding ethics motivated the collaboration with Dr. Waymond Rodgers. She is interested in examining the validity of the Throughput Model developed by Dr. Waymond Rodgers for effectively solving ethical conflicts. The Throughput Model has been discussed in the following ethical settings: "Cultural and ethical effects on managerial decisions: Examined in a Throughput Model,' Journal of Business Ethics, 31, 2001, 355-367, with $W$. Rodgers. "A model capturing ethics and executive compensation," Journal of Business Ethics, 48, 2003, 189-202. 
1. the extent to which potential stakeholders contribute valued resources to the firm;

2. the extent to which they put these resources at risk and would experience costs if the firm fails or their relationship with the firm terminates; and

3. the power they have in or over an organization.

Correspondingly, Jones and Wicks argued that "the interests of all (legitimate) stakeholders have intrinsic value, and no set of interests is assumed to dominate the others" (1999, p. 207). Jawahar and Mclaughlin (2001) insist that in different stages of an organization's life cycle, certain stakeholders will be more important than others, and the strategy an organization employs to deal with each stakeholder depends on their importance to the organization relative to other stakeholders. The stakeholder per spective can be viewed as a response to the existence of entities that are legitimately interested in the behavior of a company (Gray et al., 1996; Moneva and Llena, 2000).

By considering management reporting changes over time, we attempt to describe how an organi zation's relationship with stakeholders varies with societal changes reflected by ethical positions. In this paper we combine theory and research on resource dependency theory, six major philosophical ethical positions and a decision making model to develop a descriptive stakeholder theory. The theory illustrates how social developments influence a company's decision making, why and when they are important, and how resources are distributed among primary stakeholders.

Rodgers and Gago (2001) argue that six major philosophical stakeholder ethical positions that dominate how individuals and organizations resolve decision making problems fragmented with dilem mas. The six philosophies discussed below are: psychological egoism, deontology (e.g., procedural and distributive justice), utilitarianism, relativist, virtue ethics (e.g., organizational image), and ethics of care. This paper examines how economic, social, and political changes have affected how companies view their stakeholders as reported by the manage ment discussion is the annual report. A global company is examined in this paper to determine if during the last 75 years there has been a funda mental shift of its philosophy as reported in their annual report to stakeholders, namely psychological egoism, deontology, utilitarianism, relativist, virtue ethics, and ethics of care. We concur with Jawahar and Mclaughlin (2001) in that firms have an orga nizational life cycle stage, and that different firms may stay in different stages at the same moment of time. Further, we are not claiming that only one philosophical viewpoint dominates companies' reporting practices, but that there appears to be a changing trend of philosophies building on one another.

This paper is divided into three major sections. First, we discuss resource dependence theory in relationship to changing ethical positions over time. Second, to better understand this societal trend we relate the six major philosophical stakeholders ethical positions to a decision making model used in man agement (Rodgers and Gago, 2001). We believe that it is instructive to match ethical positions to man agers' various ways in arriving at a decision. This approach takes the conceptual philosophical posi tions one step further by operationalizing them in a goal oriented model. Third, we relate a company management discussion in their financial statements to the ethical and business transformation over the last 75 years. Fourth, we summarize the importance of the central theme of this paper.

\section{Resource dependency theory relations to stakeholders}

We assert that resource dependency theory (Pfeffer and Salanick, 1978) provides the framework for assessing the relative importance of primary stake holder groups to an organization. Organizational activity is structured around the need for resources. Companies need raw materials, access to markets, specialized skilled labor, knowledge, information, and regulatory clearance, etc., to function. Organi zational units need access to funding and direction from other units. The structure of organization and the structure of asset utilization orients around ensuring continuing access to these resources.

When internal resources are insufficient and funds must be obtained externally, exchange mar kets appear. Markets are the arrangements of 
exchange relations enabling access to desired re sources. The exchange relations within markets are based on resource dependencies and the need to coordinate activities across interests of the stake holders. These markets may be traditional external markets or internal exchange forums within orga nizations.

Dependency is a state in which a company relies on the actions of a stakeholder to achieve particular outcomes (Frooman, 1999). Therefore, a stake holder with discretion over allocation only has power if it has the "ability to articulate a credible threat of withdrawal" of those resources (Pfeffer and Leong, 1977, p. 779). Frooman (1999) further added that withholding strategies determine whether a company obtains a resource, whereas usage strategies seek to attach conditions to the continued supply of that resource. In either case, a stakeholder uses its resource relationship with the firm to leverage that demand.

Resource dependency theory indicates that firms will pay more attention to stakeholders who control resources critical to the organization than to stake holders who do not control vital resources (Pfeffer and Salancik, 1978). We argue that over the last century, society has graduated through an agrarian commerce age overtaken by an industrial techno logical period changing into an information age and now at the beginning of a broader stakeholders' ethical concern period.

At the start of the last century (e.g., 75 years ago in our company example), profitability was the main objective for their operations. We liken this period of time as the changing from the agrarian commerce age and popularized by psychological egoism philoso phy. Psychological egoism stresses that individuals are always motivated to act in their perceived self interest. The primary stakeholder was the share holder. There was a push for more legislation due to the paucity of laws governing industrial companies that required more workers, machines and factories. This period of time depicts the deontology viewpoint that emphasizes the rights of individuals and on the judgments associated with a particular decision process rather than on its choices. Companies began to pay more attention to stakeholders such as the government and its employees. Resource depen dency theory suggests that firm behavior becomes externally influenced because it must attend to the demands of those in its environment that provide resources necessary for survival (Pfeffer, 1982). This changing policy reflects the utilitarian position that is concerned with consequences, as well as the greatest good for the greatest number of people. As multi national companies' products and services began to expand their boundaries into other countries so did their attitudes. Companies' methods of operations and philosophies changed from country to country. Stakeholders were only considered in certain geo graphical areas, political contexts, etc. This high lights the relativist perspective that assumes that companies' management use themselves or the people around them as their basis for defining stakeholders' relations. In the dawn of the informa tion age augmented by newly placed orbital satel lites, companies' actions were instantaneously beamed around the world. Multinational companies were confronted with public relation problems in dealing with stakeholders such as foreign govern ments, political and social action groups. In order to boost their images the virtue ethics outlook took hold of companies' management, whereby the cultivation of virtuous traits of management's character was viewed as its morality's primary function. Finally, a broader stakeholder ethical viewpoint begin to emerge as society demanded more from companies in terms of the treatment of people and the envi ronment. This viewpoint represents the ethics of care philosophy which is a set of character traits that echo ingrain values in close personal relationships, such as sympathy, compassion, fidelity, love, friendship, and the like.

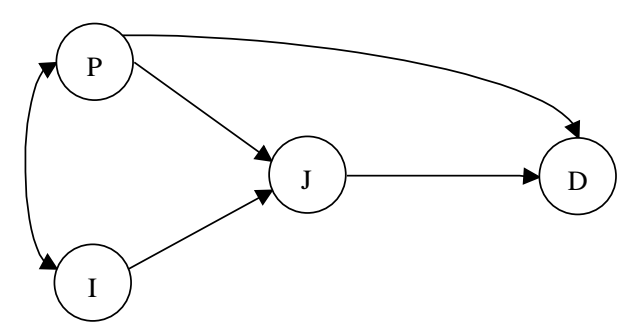

Figure 1. Individuals' decision processes diagram, where $\mathrm{P}$ - perception, I - information, $\mathrm{J}$ - judgment, and D decision choice. 


\section{Ethics and Decision-Making}

Donaldson and Preston (1995) states that stakeholder theory focuses on managerial decision making. In addition, Jones and Wicks (1999) asserts that al though there is wide acceptance for moral processes and outcomes based on the view that the claims of stakeholders have intrinsic value; however, there is a paucity of agreement on what those moral processes and outcomes should be. The model proposed here takes a unique approach to conceptualizing six eth ical philosophical positions by applying a decision making model to understanding this behavior within an organizational setting (Rodgers and Gago, 2001). The model provides a broad conceptual framework for examining interrelated processes that impact on decisions affecting organizations (Nutt, 1998; Trevino and Youngblood, 1990). It incorporates the constructs of perception (framing), information, judgment (analysis of information/experiences), and decision choice as it applies to organizations. This decision making model has shown to be useful in conceptualizing a number of different issues impor tant to organizations (Culbertson and Rodgers, 1997; Rodgers, 1992, 1999). The unique contribu tion of this model is that it clarifies critical pathways influenced by ethical positions. The three phases in the model proposed here appear with some consis tency in the literature. These are (a) perception and information gathering, (b) analysis of information and processing (i.e., judgment), and (c) choice. This model represents a parsimonious way in capturing major concepts about organizations. Further, it provides a more interpretative cognitive schema. Finally, this model conceptualizes an early warning system for organizations (Culbertson and Rodgers, 1997).

The conceptual model of ethical considerations is presented in Figure 1. Arrows from one construct to another indicate the hypothesized causal relation ships. The intensity of an ethical issue relates to the perceived importance of the issue to the decision maker (Jones, 1991). Ethical issue intensity, then, can be defined as the perceived framing of an ethical issue to the individual or group (Franke et al., 1997). Nutt added that "Studies of strategic decision making suggest that decisions are framed by stake holders who call attention to seemingly develop ments by making a claim... The concerns and needs identified by stakeholders in the claim are examined by a decision maker who weighs the wisdom of taking action" (1998, p.195). In our model, the perceived framing of ethical issues has been found to have a strong impact on both ethical judgment and choice (Robin et al., 1996).

In the model, perception and information are interdependent. That is, information can influence the way a decision maker frames a problem (per ception) or their framing can influence the selection of information to be used in later analysis. The higher the coherence between perception and information generally indicates that the information set is more reliable and relevant. Further, this interdependence implies that perception can influ ence the type of information selected for further processing. Likewise, information can influence and/or alter previous established perceptions. Information is later stored in memory affects and contributes to decision makers' analysis. Typically, before an individual can make a decision, that individual encodes the information and develops a representation for the problem (Johnson Laird, 1981). Finally, perception and judgment can affect decision choice. Some authors, notably Kahneman and Tversky (1982), suggest that automatic, per ception like heuristics and more deliberate infor mation processing strategies (judgment) are involved in most decision choices. Errors, biases, and context dependent heuristics may result from cognitive mechanisms of which decision makers are largely unaware, and these may have a direct impact on decision choice (Rodgers, 1999). The strategies of

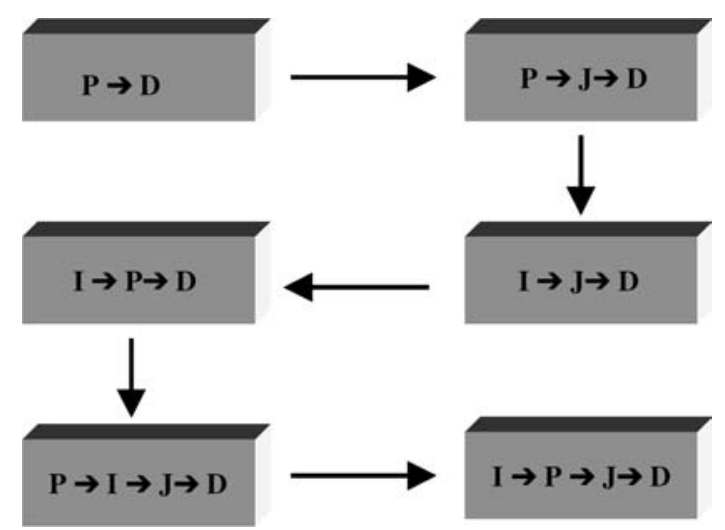

Figure 2. 75 Years of corporate ethical transformation. 
judgment that influence decision choice are under an individual's deliberate control. Our model helps us understand what causes individuals to act in a manner that we decide are unethical. Ethical behavior is a prerequisite for a society to function in an orderly way (Kahn, 1990).

The decision making processes of individuals can be represented in an organized manner. In order to study the methods of these decision processes it is important to break up all the paths marked with arrows in Figure 1 into sets of individual pathways. These fragments can then be independently analyzed for their contributing properties to individuals' decision processes (Rodgers, 1997). Further, it is common for decision makers to differ in their moral philosophical values. Even if two individuals agree on the ethical principles that determine ethical behavior, it is unlikely that they will agree on the relative importance of each principle. These differ ences are highlighted in Figure 1, depicting several pathways toward making a decision.

Based on Figure 1, we can establish six general pathways ${ }^{1}$

$$
\begin{aligned}
& \mathbf{P} \rightarrow \mathbf{D} \\
& \mathbf{P} \rightarrow \mathbf{J} \rightarrow \mathbf{D} \\
& \mathbf{I} \rightarrow \mathbf{P} \rightarrow \mathbf{D} \\
& \mathbf{I} \rightarrow \mathbf{J} \rightarrow \mathbf{D} \\
& \mathbf{P} \rightarrow \mathbf{I} \rightarrow \mathbf{J} \rightarrow \mathbf{D} \\
& \mathbf{I} \rightarrow \mathbf{P} \rightarrow \mathbf{J} \rightarrow \mathbf{D}
\end{aligned}
$$

There are many philosophies, which are complex in nature. We discuss six prominent approaches depicted in the model's six general pathways. The six philosophies discussed below are psychological egoism, deontology, relativist, utilitarianism, virtue ethics, and ethics of care. We argue that these six "time transition" philosophies are part of what are driving companies in terms of their operations (see Figure 2).

These six pathways are viewed as the most dominant and influential for decision making dom inated by particular moral perspectives. Although, it is important to note that other pathways in the de scribed decision making model also contribute to the above philosophical positions. As discussed in Rodgers and Gago (2001) the corresponding path way to each particular philosophical view is the most dominant. Other pathways may also have a parallel processing effect (Rodgers, 1991), but the weights on these pathways are not as significant.

(1) $\mathbf{P} \rightarrow \mathbf{D}$ represents psychological egoism that is based on individuals and firms existing solely to serve their own ends (Bowie, 1991). Further, Hobbes (1926) claimed that human nature is characterized by selfishness and that human behavior is primarily driven by self interest. ${ }^{2}$ A circumstance is perceived and the decision is taken by downplaying previous judgment or information. Psychological egoism in its purest form is the manifestation of maximizing shareholder wealth. In economics, the neoclassical marginal analysis regards the firm as a profit maxi mizing unit (Cyert and Hedrick, 1972). The main stay of this perspective is that shareholders differ from other constituencies since they are residual risk bearers and they have unique problems of contracting, that are best met by having control. In addition, agency theory supports the notion share holders are residual risk bearers and are in the best position to ensure that firms operate efficiently and create the greatest amount of wealth. An agency relation is one in which one person, called the agent, agrees to act for the benefit of another, the principal.

However, Freeman (1984) states that "the stake holder approach is about groups and individuals who can affect the organization, and is about managerial behavior taken in response to those groups and individuals (1984, p. 48). Jones and Wicks (1999) note that stakeholder theorists tend to believe in

1. the "intrinsic worth of the claims of all legiti mate stakeholders" (p. 211),

2. the rejection of ethical egoism,

3. a concern for others,

4. the compatibility of morality and capitalism, and the view that a healthy and efficient capi talism requires a fairly high level of morality.

Finally, Donaldson (1999) claims that most indi viduals whether stakeholder defenders or critics, reject ethical egoism, endorse concern for others, and believe that morality is at least compatible with capitalism.

$\boldsymbol{P} \rightarrow \boldsymbol{D}$ example: The International Foundation for Labor Rights asserts that there is a strong tradi tion tolerating the child labor in several countries, 
such as China, Pakistan, Thailand, Indonesia or In dia. In these countries children are perceived as an inexpensive work force $(\mathrm{P})$ for labor use (D).

(2) $\mathbf{P} \rightarrow \mathbf{J} \rightarrow \mathbf{D}$ depicts the deontology viewpoint that emphasizes the rights of individuals and the judgments associated with a particular decision pro cess rather than on its choices. Decision making is judgment oriented conditioned by one's perception of the rules and laws. The individuals have rights and duties in a society. The decision is induced by a judgment based on a perception of a circumstance.

Different forms of rule based decision making have emerged in the literature. For example, words such as respect for the leader, charisma, etc., are often used to explain how decisions influence companies' operations. Waldman and Yammarino (1999, p. 266) point out that some scholars consider that leadership style is an important ingredient for rule based decision making in organization. Also, actor based theory indicates that individuals have different rule based motivations (emotional, retrib utive, etc.) for pursuing their goals. Based on actor based theory, O'Leary et al. (2000, p. 373) define sexual harassment as: "sexual, work-related action taken with the expectation of imposing harm on another person or forced his/ her compliance in order to achieve some valued personal goal." Finally, emotional capability and intelligence theory considers individuals using rule based emotional states for decision making purposes. For example, Inguyen (1999) presents a multilevel theory of emotion linked to decision choices.

Another aspect of deontology is that it under scores the property rights perspective, which answers puzzling questions that occurs in corporate law. This corporate form of business organization is justified on the grounds that it represents an extension of the property rights and the right of contract enjoyed by everyone. That is, since individuals have the right to conduct business with their own assets, corporations are entitled a right to contract with others for the same purpose (Colquitt et al., 2001; Masterson, 2001). For example, Gilliland (1993) argues that procedural justice from a legal perspective empha sizes the role of process control or "voice" of the individual in fairness perceptions. Further, Distrib utive justice theories propose that individuals will evaluate distributions of outcomes with respect to some distributive rule such as equity (Cohen, 1987).
Ethical considerations come into play in difficult cases where the rules are unclear or in conflict.

There are two major conceptualizations of deontology (justice) among theorists (Singer, 1997). First, is the Kantian's view that involves pure prac tical reason in the formulation of absolute moral rules, which obey the principles of reversibility and universaliability. Second, is Rawls (1993) theory of justice that deals with the just allocation of limited societal resources.

$\boldsymbol{P} \rightarrow \boldsymbol{J} \rightarrow \boldsymbol{D}$ example: The international com munity has a negative impression (P) of children working $(\mathrm{P})$. That is, children working at a very early age, spend too many hours working and, therefore, do not participate in the things that chil dren perform, do not have access to education, re ceive reduced salaries, and suffer physical and psychological consequences, etc $(\mathrm{J})$. The decision is to introduce laws for preventing it. Thus, in 1989, most of the countries of the world (except for Cook Islands, Somalia, Oman, Switzerland, Arabian Emirates and U.S.) signed the Convention on Children Rights to protect the children against the economic exploitation. Nearly 50 countries have agreed on the Convention 138 of the Work Inter national Organization about minimum ages for working, which establishes more rigorous norms than before. ${ }^{3}$ Hence, Many nations have signed covenants against children.

(3) $\mathbf{I} \rightarrow \mathbf{J} \rightarrow \mathbf{D}$ reflects the utilitarian position, which is concerned with consequences, as well as the greatest good for the greatest number of people. Utilitarianism is based on collective "economic egoism". The judgment is based on information and the information conditions the decision. The central theme is what is good for the company is good for the country or community. Utilitarianism is an expansion of psychological egoism in that it is committed to the maximization of the good and the minimization of harm and evil to a society. Utili tarianism can be traced to the English political phi losopher Bentham (1962), who designed a calculus in weighing criminal behavior and corresponding punishment. This calculus was extended to value judgments by the principle of maximizing happiness and minimizing pain. This calculus formed the basis of later utility calculations (i.e., cost benefit analysis) in act utilitarianism. Mill (1957) is associated with 
the new version of utilitarianism (i.e., rule utilitari anism) that accommodates the moral values of rights of duties. In this method, utility maximizing prin ciple is not directly applied to the action itself, but is only applied to an abstract rule that is to govern moral judgments as follows:

1. an action is moral if it follows morally correct rules, and

2. a rule is considered morally correct if the net utility produced when everyone acts on that rule is greater than the net utility produced when everyone acts on any other alternative rule.

Smith (1991) stated over 200 years ago that "every individual is continually exerting himself to find out the most advantageous employment for what ever capital he can command. It is his own advantage, indeed, and not that of the society, which he has in view. But the study of his own advantage naturally, or rather necessarily, leads him to prefer that employ ment which is most advantage to the society." Fur ther, Friedman (1970) argued that the purpose of the corporation is to seek profits for stockholders while acting in conformity with the moral minimum. Corporations may strive for profits as long as they commit no deception or fraud. Zahra et al. argued that some governments use privatization as "a means of transplanting a procapitalistic political ideology by liberalizing the economy, promoting foreign invest ment, infusing new technology, and increasing na tional standards of living" (2000, p. 13). Further, creativity research illustrates how individuals con tribute to the overall goal of profit making by resolving conflicts and gathering a consensus that benefits the entire organization (Drazin et al., 1999; Unsworth, 2001). Finally, Leana and Van Buren indicate that "Organizational social capital is realized through members' levels of collective goal orientation and shared trust, which create value by facilitating successful collective action" (1999, p. 538). The organizational outcomes relate to benefits (commit ment justification, intellectual capital, etc.) and costs (maintenance costs, institutional power, etc.) (Dess and Shaw, 2001, Nahapiet and Ghoshal, 1998).

$\boldsymbol{I} \rightarrow \boldsymbol{J} \rightarrow \boldsymbol{D}$ example: In spite of the fact of increasing international rejection regarding con tracting children as workers, some companies ob served the reduced cost of salaries in Asia (I). As a consequence they analyzed their economic benefits from this situation $(\mathrm{J})$ and decided to contract chil dren labor in order to increase shareholders' wealth (D). Thus, American and European companies, such as Nike, Adidas, Mattel, Lego, Chicco, used or still use children for work in their Asiatic plants (D). For example, Adidas transferred most of their production to Asia, closing its Europeans plants.

(4) $\mathbf{I} \rightarrow \mathbf{P} \rightarrow \mathbf{D}$ highlights the relativist perspective, which assumes that decision makers use themselves or the people around them as their basis for defining ethical standards. Relativism is a function of a company operating differently due to the rules or laws (or lack thereof) governing another country. Current information influences perception and the ultimate decision without a previous judgment. This information influences a company's perception to act in a particular manner; that is information is examined, the perception is framed and the decision is adopted. The relativism viewpoint dominated as companies began to emerge into multinational or global organizations with its homebase centered in one country. The relativism viewpoint focuses on firm efficiency and wealth creation. Hence, the objective of the firm is generally expressed as shareholder wealth maximization (Modigliani and Miller, 1958). Relativism exists, since many coun tries prohibit companies from committing deception or fraud at home; however, these countries take no action when deception or fraud acts are committed abroad. This affects otherwise honest people to jus tify their actions because they are not illegal. In the case of bribery Nigeria, for example, has a appalling reputation for corruption. This, however does not translate into all Nigerians are corrupt or condone the practice. In Wyburd (1998, p. 50), he states that Nigeria Head of State General Obasanjo made the following speech at Entebbe Uganda in 1994: "it is simply a self serving justification of reprehensible conduct for businessmen of the North to claim that only by lavishly entertaining African leaders and educating their children can any one do business on this continent." On a grand scale relativism can become a moral threat to society in general and to democracy in particular.

Relativism can also be explained in part by insti tutional theory. That is, organizational practices are 
"particular ways of conducting organizational func tions that have evolved over time under the influence of an organization's history, people, interests, and actions that have become institutionalized in the organization" (Kostova, 1999, p. 309). Since institu tionalized practices vary widely, transnational transfer of strategic organizational practices is an example of this approach (Kostova, 1999). Newman (2000) refers to the organizational transformation in Central and Eastern Europe, pointing to the singularities of this process in relation to other organizational changes. She demonstrates that institutional change may pro duce weaker conditions in the rate of organizational learning and organizational transformation.

Birkinshaw and Hood (1998) also affirm that local environment can affect the subsidiary role in mul tinationals. Thus, different environments may be an explanation for different decisions made by the head office and the subsidiary. In the case of envi ronmental regulation that differ among countries, some companies obtain economic advantages from lenient regulations (Nehrt, 1998).

$\boldsymbol{I} \rightarrow \boldsymbol{P} \rightarrow \boldsymbol{D}$ example: In 1991, lenient child labor laws (I), allowed Nike to lower its expenses, thereby increasing profitability $(\mathrm{P})$. Hence, Nike employed children in its Asian manufacturing process of sport shoes (D).

(5) $\mathbf{P} \rightarrow \mathbf{I} \rightarrow \mathbf{J} \rightarrow \mathbf{D}$ under scores the virtue ethics outlook which is the classical Hellenistic tra dition represented by Plato and Aristotle, whereby the cultivation of virtuous traits of character is viewed as morality's primary function. In Aristotle's moral philosophy, the notion of virtue is central. Virtues are ideal traits that are necessary for an individual to attain a state of harmony within one, and to attain such a state in relation to his social environment. Aristotle identified the following traits as basic human virtues: justice, courage, temperance, liberality (not miserliness), magnifi cence (generosity), pride, shame, honor, good temper, friendliness, wittiness and truthfulness. Virtues do not represent absolute rules and should be defined in terms of a purpose (telos).

In the virtue ethics perspective, a circumstance is perceived. A conscious look for information is ini tiated. Based on the information a judgment is made, which will support a decision. Virtue ethics outlook began to rise during the 1960s prompt by television and other mediums of advertising. The corporate image began to change to assume a disposition to act fairly but also a morally appropriate desire to do so. Well known celebrities endorsed products and cor porate leaders appeared to have the traits of a vir tuous character. Gioia et al. (2000) summarize the literature on organizational image as a wide ranging concept connoting perceptions that are both internal and external to the organization, as well as percep tions that are both projected and received. The organizational image viewed by different individuals and groups (community, women and minorities employees relations, etc.) can influence decisions made by a firm's profit sharing schemes (e.g., investment managers, pension funds, top manage ment team equity and outside directors, etc) (Forbes and Milliken, 1999; Johnson and Greening, 1999; Prestholdt et al., 1987).

The social network perspective provides support for the virtue ethics perspective in that it considers individuals involved in relationships with other individuals creating different ties. That is, social network provides a basis on which individuals are provided with information and then establish their decision making with ethical and unethical conse quences (Higgins and Kram, 2001). For example, mentoring at work comprises mutually, reciprocity, multilevel, and career development of minorities (Brass et al., 1998). Bhappu (2000) affirms that individual behavior in Japanese corporate networks shows values such as loyalty, power, etc. Also, employees use work tasks, jobs, their lives, social context etc., to build the experience of their jobs. Job crafting is defined as "the physical and cognitive changes individual make in the task or relational boundaries of their work" (Wrzesniewski and Dut ton, 2001, p. 179). Their purpose is achieving a better control and creating a positive image at the workplace.

$\boldsymbol{P} \rightarrow \boldsymbol{I} \rightarrow \boldsymbol{J} \rightarrow \boldsymbol{D}$ example: Companies observe several factors that may contribute to their political risk: That is, contracting of children may cause their customers to reject their products $(\mathrm{P})$ and, as a consequence the company's market value and image suffers. Thus, they experience economic backlash due to negative public opinion not only in sport shoes sales, but also in their other product lines (I). They analyze the need to change public opinion by demonstrating that they are moving away from foreign child labor (J). Hence, Nike and Reebok 
decided to make public that their soccer balls were not made with children labor (D).

(6) $\mathbf{I} \rightarrow \mathbf{P} \rightarrow \mathbf{J} \rightarrow \mathbf{D}$ represents the ethics of care philosophy, which focuses on a willingness to listen to distinct and previously unacknowledged perspec tives. In other words a company must build solidarity among employees, suppliers, customers, sharehold ers, and the community. The ethics of care per spective is similar to other types of board theories covering different stakeholder groups (Korsgaard et al., 1997). For example, Jones and Wicks (1999) mentioned feministic ethics as an example of ethics of care, whereby companies' actions are tempered by not harming any stakeholders. Also, Berman et al. (1999) distinguishes among normative, instrumental and descriptive/empirical types of stakeholder the ory. Normative stakeholder research deals with how managers should make decisions taking into account stakeholders. Instrumental research is concerned about how to deal with problems, conflicts, etc., with stakeholders in practice. The descriptive/empirical approach is centered on what occurs in the rela tionship between managers and other stakeholders.

The ethics of care philosophy states that important information exists that influences one's perception of a circumstance. The influenced perceptions are judged and a decision is made. Also, ethics of care viewpoint emphasizes that not only shareholders have property rights but also employees, suppliers, customers, and the community. Therefore, property rights and the right to contract with every corporate constituency and not from those of shareholders alone shape corporation actions. Hu (1990) advocates that the shareholder wealth maximization paradigm needs reinterpretation. That is, because the firm va lue is viewed as an "ongoing concern," and is capable of creating future wealth for society, then managers should consider the interests of all of the groups that make up the corporation. Also, Cornell and Shapiro (1987) advised that the firm value should include implicit claims to various constituencies and the costs to the firm of honoring these claims. Respectively, these represent organizational capital and organiza tional liabilities. The difference between the two is a form of wealth that is not recorded by traditional financial accounting practices.

$\boldsymbol{I} \rightarrow \boldsymbol{P} \rightarrow \boldsymbol{J} \rightarrow \boldsymbol{D}$ example: As a consequence of the "shoes affair," companies that work in Asia re ceived economic and non economic information about the negative impact on their business of

Table I

Firm's strategic policy

\begin{tabular}{ll}
\hline Degree of firms' dependence on stakeholders & Strategy \\
\hline No & Psychological egoism \\
Low & Deontology/Utilitarianism \\
Medium & Relativism \\
High & Virtue ethics outlook/ Ethics of care \\
\hline
\end{tabular}

Table II

Firm and stakeholders' interdependencies

\begin{tabular}{lll}
\hline \multirow{2}{*}{ Degree of the firm' dependence on the stakeholder } & \multicolumn{2}{l}{ Degree of the stakeholder' dependence on the firm } \\
\cline { 2 - 3 } & Low/Medium & Low/Medium \\
\hline Low/Medium & A & B \\
& Deontology/Utilitarianism: & Psychological egoism \\
Medium/High & Low interdependence & Deontology: Firm power \\
& C & D \\
& Virtue ethics outlook/Ethics Relativism/Virtue ethics \\
& of care: Stakeholders power & outlook: High interdependence \\
\end{tabular}


contracting children (I). They perceived the eco nomic and ethical problems derived from this information set $(\mathrm{P})$. They rendered a judgment for eliminating the practice of contracting children $(\mathrm{J})$ and decided to implement policies oriented to it (D). For example, Nike, associated with a Pakistan company, opened a plant for manufacturing soccer balls in which the labor force did not include chil dren. In 1996 Reebok published that their balls will be guaranteed as made without children work for the spring of 1997.

In summary, Frooman (1999) establishes a typol ogy of resource relationships answering to two questions: (a) is the firm dependent on the stake holders? (b) is the stakeholder dependent on the firm? The firm viewpoint is to develop strategies without being "punished" by stakeholders when it is not dependent on the stakeholders. In a market of offer, the firm is not as dependent on a stakeholder such as a customer. Thus, that stakeholder can be ignored without consequences. However, as the degree of dependence increases, the company will tend to adopt strategies that take into account how the stakeholder will react. Hence, a strategic policy of psychological egoism indicates no dependence on stakeholders; whereas high dependence relates to a policy of virtue ethics or ethics of care (Table I).

Stakeholders' dependence allows a company to impose its philosophies. Cell A in Table II depicts the situation where both the firm and the stake holder are strongly influenced by customs, rules, laws etc. Actions taken by the company are considered to be best for the community or the nation.

In cell $\mathrm{B}$, stakeholders are dependent on the company, and the company is not dependent on the stakeholder. In this case, an organization may base its policy on rules or in the case of a start up company; the policy may favor psychological egoism. In the cell C situation, the stakeholder holds the power. In this scenario, the stakeholder does not depend heavily upon a company, whereas the company is dependent on stakeholders. Due to organizational image or gender consideration, a company may adopt a virtue ethics or ethics of care policy. Finally, cell D represents "high interdependence." Given that a company and its stakeholders are mutually dependent then a policy of relativism or virtue ethics may prevail.
In summary, a company may develop a decision making strategy based upon a psychological egoism viewpoint without suffering significant external pressure when stakeholder depends highly on the firm (Pfeffer and Leong, 1977). Relativism would be for medium situations in which a dominant course of action is not consistently applied throughout the organization (Rodgers and Gago, 2001). If the firm dependence on the stakeholder is high (Frooman, 1999), then virtue ethics or ethics of care viewpoints becomes a firm strategy (Table II).

\section{Management discussion in the Annual Reports}

This section discusses how the philosophies of psy chological egoism, deontology, utilitarianism, rela tivist, virtue ethics, and ethics of care impacted on approximately 70 years of Coca Cola's operations. The management discussion section of the annual reports for the last 75 years was used as a basis for our analysis. Further, we include certain annual report statements and quotes to facilitate our argument pertaining to a particular philosophical viewpoint. The inclusion of these comments is by no means the only points made by management of these compa nies. Social and political trends however, appear to influence the way companies report their financial statements.

\section{Coca-Cola Company}

Psychological egotism is clearly present in the actions of Coke's chief executive, Robert Woodruff, during the 1920s. His decision to incorporate the "new" company in Delaware, a state known for lenient corporate taxes, is indicative of the desire to maxi mize profits. His plan to avoid paying taxes by issuing shares of common stock to the public at no set par value indicates the desire to maximize the profits of the Coca Cola Company (Pendergrast, 1993). During the 1920s, the value of Coca Cola Stock went from its initial public offering of $\$ 5$ to $\$ 134$ in 1929.

Deontology. After the freewheeling profits of the 1920s, a new ethical model was taking shape. Deontology stressed the importance of the right of 
individuals. That is, during the 1930s, the United States Congress began passing laws to protect the rights of consumers against the profit hungry corporations of the day. Laws such as the Sherman Antitrust Act, passed in 1890, were being enforced again against companies participating in unfair business practices designed to drive competitors out of business. In the 1935 Letter to Shareholders, Rob ert Woodruff, stated, "In light of the changing business environment due to the increasing involvement of the government to protect the consumer, I am happy to report that the Coca Cola Company does not engage in activities that harm consumers or that stifle the competition" (Coca Cola, 1935).

Utilitarianism. The 1940s were plagued with global instability. The Second World War was ravaging Europe and destroying the manufacturing facilities and the infrastructures of what were then some of the world's strongest nations. During this time, the utilitarianism ethical framework was applied. This framework focuses on the consequences of decisions and how to create the greatest good for the greatest number of people. The Coca Cola Company was able to thrive and establish a global presence during this time period due to the war effort. The company had begun setting up international operations in Canada, Cuba, and Germany but was hardly present in any other country.

Relativism. Following World War II, much of Eur ope had been bombed out. Their factories had been destroyed. The ravages of war had annihilated many roads, bridges, and infrastructure. This created a vacuum in terms of supplying products to Europe. Many U.S. companies were able to enter global markets, without major competition from foreign firms, due to the vacuum that the war created in Europe.

During this time, companies were able to get around U.S. laws when selling their products over seas. For example, the same laws regarding quality or materials used did not apply to goods not being sold in the United States. The expatriates who were working abroad took on a new set of values. Many, upon returning to the U.S., would continue to run the company as if they were still abroad.
Virtue ethics. The invention of the television pro vided the American people, for the first time, instant access to information. Companies' images were influenced by investments in advertising and mar keting. The consumer advocacy movement led by Ralph Nader was a little young in 1950 began to pick up speed during this time. People could now see how a Ford Pinto exploded upon a rear impact. Companies had to react to consumer needs more quickly because the consumer now had instant access to information. They were able to hear the com ments and interviews of CEOs as they were made and that forced CEOs to be more cautious as to what they said publicly.

In 1963, Coca Cola introduced the campaign, “Things Go Better With Coke." Then president John F. Kennedy was photographed in 1963 drinking a Coke and the company used that to its advantage. Kennedy was not only the president of the United States but was widely popular among the American populace. In 1965, Coca Cola began using adver tisements that showcased African Americans. Barbara McNair became the first African American in a Coke advertisement. Ray Charles, The Supremes, The Fifth Dimension, Gladys Knight and the Pips all sang the message "That Things Go Better With Coke." Coke attempted to change its image and position itself as the cola for the new generation that was developing in the 1960s (Pendergrast, 1993).

The ethics of care philosophy. During the 1980s and 1990s the ethics of care philosophy began to emerge. Companies realized that they could earn higher profits if they were good citizens of the community. Consumers were willing to support a company that had a good reputation. Companies could also avoid the regulations and laws that stemmed from public outrage if they were responsible members of the community. The environment and its protection also became important.

The passage of the Mutual Fund Act during the late 1970s also played a significant role during this time period. This Act facilitated the shareholder movement. Sixty to seventy percent of all out standing shares are owned by institutional investors, i.e., pension funds, mutual funds, and insurance companies, with individuals being the ultimate owners of these shares. They have the ability to exercise a lot of power in the company. The 
stakeholders now become intertwined with the company.

In the 1983, Letter to Shareholders, Robert Goi zueta, Chairman of the Board and Chief Executive Officer, talked about the company's philanthropic acts such as donating money to local schools, partic ipating in recycling programs and improving the plight of children in developing countries. This strategy had obvious financial rewards for the com pany. In 1982, the company achieved a $21 \%$ return on shareholders' equity. In 1991, the Goizueta declared that the market value of the Coca Cola Company increased by 5 billion dollars in 1990, an amount greater than the total market value in 1981. The re turn on common shareholders' equity exceeded 39\%, the highest return in more than 50 years.

\section{Conclusion}

This paper presented resource dependency theory in explaining six major philosophical theories of psy chological egoism, deontology, utilitarianism, rela tivist, virtue ethics, and ethics of care relate to the last century of companies annual reporting. Emphasis was placed on embedding these philosophies into a process decision making model that could help guide our understanding to the type of decisions manage ment makes. We discussed from a historical per spective that society has graduated through an agrarian commerce age overtaken by an industrial technological period changing into an information age and now at the beginning of stakeholders' ethical concern period. A descriptive analysis was made of a global company's annual reports for the last 75 years in order to determine if these periods changes were also governed by philosophical changes as well. We found evidence from companies' annual reports that these philosophies have strongly influenced compa nies' management reporting and have shifted their mission in reporting the results of operations and financial status.

Global companies have a significant effect on the way business is transacted worldwide, and they have penetrating influences on our political, social and environmental structures. For example, many global companies' annual reports discuss how their non profit sectors have contributed heavily to the arts, education and the community. While the next millennium will bring about new products and unexpected challenges, the changes in individuals' ethical philosophies will continually impact upon global corporations' management reports.

According to our framework, the ethics of care philosophy or a broader stakeholders' perspective maybe the beginning of not only how companies relate to its community and others, but also how their influential forces may spill over and affect individuals in society to learn to cope with different cultures and nationalities. In sum, this paper helps to crystallize the trend of reporting information to the public by relating the changing philosophical posi tions within a well tested decision making model.

\section{Notes}

${ }^{1}$ We use negative and positive signs to represent the depth of coherence of the variables on a particular path. A positive sign implies strong coherence while a negative sign implies a weak one, respectively. In order to give direction to a necessary pattern, we assume that any coefficient that is larger than or equal to 0.5 , in absolute value, will be considered supportive of a high coherence and thus will receive a positive sign, while any coefficient that is smaller than 0.5 , in absolute value, receive a negative sign and imply a weak coherence of the variables associated with that path. The sign of the flow is dependent upon the relative importance of the use of that pathway for reaching a decision.

In Figure 1, weak pathways are either $(-)$ or $(\mathbf{0})$. In other words, all the paths drawn are the pathways with large absolute value coefficients, thus they are the ones influencing individuals' decision choices the most. All the pathways drawn represent logically possible pathways that yield decisions. Even with this reduction in number of combinations, it is clear: decision makers' processes can involve a series of complicated steps. These six pathways are viewed as the most dominant and influential for decision making dominated by particular moral perspec tives.

${ }^{2}$ Ethical egoists have differed in their conception of the "goodness" of consequences (Singer, 1997). That is, the extreme egoists (i.e., hedonism) define goodness exclu sively in terms of pleasure (physical or materialist pursuits); while others centered on less physical or material forms in defining goodness. Ethical egoists also argue that an individual is not concerned about others' 
welfare in order to serve the common good. Egoists are concerned about others only when such concerns serve as a means to achieve their own self interests.

3 Minimum age for working: 15 years in industrial countries and 14 in the others; in soft works: 13 and 12 respectively, if the work menaces the health: 18 years.

\section{References}

Bentham, J.: 1962, The Works of Jeremy Bentham (John Bowring, London).

Berman, S., A. Wicks, S. Kotha and T. Jones: 1999, 'Does Stakeholder Orientation Matter? The Rela tionship Between Stakeholder Management Models and Firm Financial Performance', Academy of Manage ment Journal 4, 488-506.

Bhappu, A.: 2000, The Japanese Family: An Institutional Logic for Japanese Corporate Networks and Japanese Management', Academy of Management Review 25, 409415.

Birkinshaw, J. and N. Hood: 1998, 'Multinational Sub sidiary Evolution: Capability and Charter Change in Foreign Owned Subsidiary Companies', Academy of Management Review 23, 773-795.

Bowie, N.: 1991, 'Challenging the Egoistic Paradigm', Business Ethics Quarterly 1, 1-21.

Brass, D., K. Butterfield, and B. Skaggs: 1998, Rela tionships and unethical behavior: A social network perspective', Academy of Management Review 23, 1431.

Coca Cola. (1935), Annual Report.

Cohen, R. L.: 1987, 'Distributive Justice: Theory and Research', Social Justice Research 1, 19-40.

Colquitt, J. A., D. E. Conlon, M. J. Wesson, C. O. L. H. Porter, and K. Y. Ng, 2001. 'Justice at the Millen nium: A Meta Analytic Review of 25 years of Orga nizational Justice Research', Journal of Applied Psychology 86, 425-445.

Cornell, B. and A. Shapiro: 1987, 'Corporate Stake holders and Corporate Finance', Financial Management 16, 5-14.

Culbertson, A. L. and W. Rodgers: 1997, 'Improving Managerial Effectiveness in the Workplace: The Case of Sexual Harassment of Navy Women', Journal of Applied Social Psychology 27, 1953-1971.

Cyert, R. M. and C. L. Hedrick: 1972, 'Theory of the Firm: Past, Present, and Future; An Interpretation', Journal of Economic Literature 10, 398-412.

Dess, G. and J. Shaw: 2001, 'Voluntary Turnover, Social Capital, and Organizational Performance', Academy of Management Review 26, 446-456.
Donaldson, T.: 1999, 'Making Stakeholder Theory Whole', Academy Management Review 24, 237-241.

Donaldson, T. and L. Preston: 1995, 'The Stakeholder Theory of the Corporation: Concepts, Evidence, Implications', Academy Management Review 20, 65-91.

Drazin, R., A. Glynn and R. Kazanjian: 1999, Multilevel Theorizing about Creativity in Organizations: A Sensemaking Perspective', Academy of Management Review 24, 286-307.

Forbes, D. and F. Miliken: 1999, 'Cognition and Cor porate Governance: Understanding Boards of Direc tors as Strategic Decision Making Groups', Academy of Management Review 24, 489-505.

Franke, G. R., D. F. Crown and D.F. Spake: 1997, 'Gender Differences in Ethical Perceptions of Business Practices: A Social Role Theory Perspective', Journal of Applied Psychology 82, 920-934.

Freeman, R. E.: 1984, Strategic Management: A Stakeholder Approach (Pitman Publishing, Boston).

Friedman, M.: 1970, 'The Responsibility of Business is to Increase its Profits', New York Times Magazine, Sep tember 13, 1970.

Frooman, J.: 1999, 'Stakeholder Influence Strategies', Academy of Management Review 24, 191-205.

Gilliland, S. W.: 1993, 'The Perceived Fairness of Selection Systems: An Organizational Justice Per spective', Academy Management Review 18, 694-734.

Gioia, D. A., M. Schultz and K. G. Corley: 2000, 'Organizational Identity, Image, and Adaptive Insta bility', Academy Management Review 25, 63-81.

Gray, R., D. Owen and C. Adams: 1996, Accounting and Accountability. Changes and Challenges in Corporate Social and Environmental Reporting (Prentice Hall, London).

Higgins, M. and K. Kram: 2001, 'Reconceptualizing Mentoring at Work: A Development Network Per spective', Academy of Management Review 26, 264-288.

Hobbes, T.: 1926, Leviathan (Hafner, NY).

Hu, H. T.: 1990, 'Risk, Time, and Fiduciary Principles in Corporate Investment', UCLA Law Review 38, 282.

Inguyen, Q.: 1999, 'Emotional Capability, Emotional Intelligence, and Radical Change', Academy of Man agement Review 24, 325-345.

Jawahar, I. M. and G. L. Mclaughlin: 2001, 'Toward a Descriptive Stakeholder Theory: An Organizational Life Cycle Approach', Academy of Management Review 26, 397-414.

Johnson, R. and D. Greening: 1999, 'The Effects of Corporate Governance and Institutional Ownership Types on Corporate Social Performance', Academy of Management Review 42, 564-576.

Johnson Laird, P. N.: 1981, 'Mental Models in Cognitive Science', in D. A. Norman (ed.), Perspectives on Cognitive Science (Erlbaum, Hillsdale, NJ), pp. 147-191. 
Jones, T. M.: 1991, 'Ethical Decision Making by Indi viduals in Organizations: An Issue Contingent Model', Academy of Management Review 16, 366-395.

Jones, T. M. and A. C. Wicks, 1999, 'Convergent Stakeholder Theory', Academy of Management Review 24, 206-221.

Kahn, W. A.: 1990, 'Toward an Agenda for Business Ethics Research', Academy of Management Review 15, 311-328.

Kahneman, D. and A. Tversky: 1982, 'On the Study of Statistical Intuitions', in D. Kahneman, P. Slovic and A. Tversky (eds.), Judgment Under Uncertainty: Heuristics and Biases (Cambridge, New York), pp. 493-508.

Korsgaard, M. A., B. M. Meglino and S. W. Lester: 1997, 'Beyond Helping: Do Other Oriented Values have Broader Implications in Organizations?', Journal of Applied Psychology 82, 160-177.

Kostova, T.: 1999, 'Transnational Transfer of Strategic Organizational Practices: A Contextual Perspective', Academy of Management Review 24, 308-324.

Leana, C. and H. Van Buren III: 1999, 'Organizational Social Capital and Employment Practices', Academy of Management Review 24, 538-555.

Masterson, S. S.: 2001, 'A Trickle Down Model of Organizational Justice: Relating Employees' and Customers' Perceptions of and Reactions to Fairness. Journal of Applied Psychology 86, 594-604.

Mill, J. S.: 1957, Utilitarianism (Bobbs Merrill, Indianap olis).

Mitchell, R. K., B. R. Agle and D. J. Wood: 1997, 'Toward a Theory of Stakeholder Identification and Salience: Defining the Principle of Who and What Really Counts', Academy of Management Review 22, 853-886.

Modigliani, F. and M. H. Miller: 1958, 'The Cost of Capital, Corporation Finance, and the Theory of Investment', American Economic Review 48, 261297.

Moneva, J. and F. Llena: 2000, 'Environmental Disclo sures in the Annual Reports of Large Companies in Spain', The European Accounting Review 9, 729.

Nahapiet, J. and S. Ghoshal: 1998, 'Social Capital, Intellectual Capital and the Organizational Advantage', Academy of Management Review 23, 242-266.

Nehrt, C.: 1998: 'Maintainability of First Mover Advantages when Environmental Regulations Differ Between Countries', Academy of Management Review 23, 77-97.

Newman, K.: 2000, 'Organizational Transformation during Institutional Upheaval', Academy of Management Review 25, 602-619.
Nutt, P. C.: 1998, 'Framing Strategic Decisions', Orga nization Science 9, 195-216.

O'Leary, A., R. Paetzold and R. Griffin: 2000, Sexual Harassment as Aggressive Behavior: An Actor Based Perspective', Academy of Management Review 25, 372388.

Pendergrast, M.: 1993, For God, Country, and Coca Cola (Charles Scribner's Sons, NY).

Pfeffer, J.: 1982, Organizations and Organization Theory (Pitman Publishing, Marshfield, MA).

Pfeffer, J. and A. Leong: 1977, 'Resource Allocations in United funds: Examination of Power and Depen dence', Social Forces 55, 775-790.

Pfeffer, J. and G. Salancik: 1978, The External Control of Organizations: A Resource Dependence Perspective (Harper and Row, NY).

Prestholdt, P. H., I. M. Lane and R. C. Mathews: 1987, 'Nurse Turnover as Reasoned Action: Development of a Process Model', Journal of Applied Psychology 72, 221-227.

Rawls, J.: 1993, Political liberalism (Colombia University Press, NY).

Robin, D. P., R. E. Reidenbach and P. J. Forrest: 1996, 'The Perceived Importance of an Ethical Issue as an Influence on the Ethical Decision Making of ad Managers', Journal of Business Research 35, 17.

Rodgers, W.: 1991, 'How Do Loan Officers make their Decisions about Credit risks? A Study of Parallel Dis tributed Processing (PDP)', Journal of Economic Psy chology 12, 243-265.

Rodgers, W.: 1992, 'The Effects of Accounting Infor mation on Individuals' Perceptual Processes', Journal of Accounting, Auditing and Finance 7, 67-96.

Rodgers, W.: 1997, Throughput Modeling: Financial Infor mation Used by Decision Makers (JAI Press, Greenwich, CT).

Rodgers, W.: 1999, 'The Influences of Conflicting Information on Novices' and Loan Officers' Actions', Journal of Economic Psychology 20, 123-145.

Rodgers, W. and S. Gago: 2001, 'Cultural and Ethical Effects on Managerial Decisions: Examined in a Throughput Model', Journal of Business Ethics 31, 355367.

Singer, M.: 1997, Ethics and Justice in Organizations. (Ashgate, Sydney).

Smith, A.: 1991, The Wealth of Nations (Prometheus Books).

Trevino, L. K. and S. A. Youngblood: 1990, 'Bad Apples in Bad Barrels: A Causal Analysis of Ethical Decision Making Behavior', Journal of Applied Psychology 75, 378-385.

Unsworth, K.: 2001, 'Unpacking Creativity. Academy of Management Review 23, 77-97. 
Waldman, D. and F. Yammarino: 1999, 'CEO Charis matic Leadership: Levels of Management and Levels of Analysis Effects', Academy of Management Review 24, 266-285.

Wrzesniewski, A. and J. Dutton: 2001, 'Crafting a Job: Revisioning Employees as Active crafters of their Work', Academy of Management Review 26, 179-201.

Wyburd, G.: 1998, Competitive and Ethical? (Kogan Page Limited, London).

Zahra, S., R. Ireland, I. Gutierrez and M. Hitt: 2000, 'Privatization and Entrepreneurial Transformation: Emerging Issues and a Future Research Agenda', Academy of Management Review 25, 509524.
Waymond Rodgers, Graduate School of Management, University of California, Riverside, CA 92521,

USA

Email:waymond.rodgers@ucr.edu

Susana Gago Social and Law Sciences School, Carlos III University of Madrid and the University of Santiago de Compostela, Santiago Spain 